\title{
Pricing Traditional Travel Agency Services: A Theatre-Based Experimental Study
}

\author{
Giuseppe Catenazzo ${ }^{1}$, Emmanuel Fragnière $^{2}$ \\ ${ }^{1}$ Haute École De Gestion De Genève, Carouge Ge, Switzerland; ${ }^{2}$ Cia, The University Of Bath, Haute École De Gestion De Genève, \\ Carouge Ge, Switzerland. \\ Email: \{giuseppe.catenazzo, emmanuel.fragniere\}@hesge.ch
}

Received January $1^{\text {st }}, 2010$; revised February $16^{\text {th }}, 2010$; accepted March $22^{\text {nd }}, 2010$.

\begin{abstract}
Airline commissions' cuts and the use of Internet for bookings have severely affected traditional (physical) travel agencies. To survive, travel agents are redesigning their job as to become travel consultants. However, customers seem not to be willing to pay for the service provided and current fees are not representative of its perceived value. We have designed a theatre-based experiment to discover the Willingness-To-Pay for a travel agency service experience. Results show that individuals are not willing to pay anything for an unpleasant experience. By contrast, only 1/3 of the sample would pay enough for an outstanding service experience to make such a business sustainable.
\end{abstract}

Keywords: Experimental Study, Theatre, Service Design, Travel Agent, Human Simulation, Service Pricing

\section{Introduction}

Travel agencies are retail intermediaries that represent a wide range of leisure and journey services [1]; the role of the travel agent is to provide travellers with information, travel documents administration and advices [2]. This type of business is remunerated through commissions collected on the wholesales [1].

In the last decade, the overall travel demand has increased (on average $+4.1 \%$ per year since 1995 , source: World Tourism Organisation, http://www.unwto.org), but not the traditional travel agencies income: the industry has been hit by changes that heavily affected their business.

First of all, traditional commission schemes to travel agencies have totally changed. Up to 1997 , about one fourth of traditional travel agencies revenue was raised through airline tickets sales commissions, $67 \%$ through other sources such as vacation and other packages sales [3]; in the following years this takings model experienced a complete transformation. This is due to the attempt of disintermediation by many travel providers and travel agencies' operational costs growth over time [2].

More precisely, airline ticket sales commissions abolition has put in danger the survival of traditional travel agencies. This policy started in the late 90s with the introduction of commissions' cuts and the introduction of flat fares to agents [4], few years later, in 2002, most world leading carriers have introduced a $0 \%$ commis- sion's policy towards their agents. This happened first in the US in March 2002 at 8 major American airlines, followed by Air Canada on April $23^{\text {rd }} 2002$, and then by all other international airlines around the world $[5,6]$. Worldwide, this revenue change in the traditional travel agencies business lead traditional travel agencies either to close or consolidate [2]. For example, in the USA, 2,707 traditional travel agencies close between 1995 and 2002 [7].

To fill up such missed income, traditional travel agencies have been diversifying their activities to alternative more profitable travel products such as cruises and tours $[2,7]$. Also, they transferred the commissions' revenue straight to their customers by introducing a booking or service fee $[2,8,9]$. However, to save such charge, most travellers have quickly turned to the Internet and to phone booking centres [2] where they can make reservations at their convenience using their own debit or credit card.

In addition to fees' schemes altering, the traditional travel agency industry has suffered because of a fast growing use of information communication (ICT) devices in the industry. The shape of the whole travel industry rapidly changed since ICT allowed tourism service providers a more easily disintermediation. Also, Internet-based agencies have entered the market and tighten competition in an industry characterised by several small independent retailers, low entry barriers, and low return businesses. Since use of the Internet for users 
has spread and become more comfortable to people, traditional agencies have been facing a more challenging competitor [10].

To survive, travel agencies need to redesign their job: at present time, they are slowly transforming themselves into travel consulting bureaus rather than booking centres $[7,11]$. This can happen since in the travel industry, information and knowledge play a strategic role [12], especially when devising composite organising and intricate travel packages [7]. Thus, according to Bennett and Lai [11], traditional travel agencies strategies need to focus on personal service to provide the customers' professional advice and added-value services. Also, they should treat Internet and other ICS as an opportunity, not as a threat.

The travel agent's job then becomes a knowledgebased service of high added value [2]. A knowledgebased service can be described as a service delivered by highly trained providers that offer a high quality service designed to meet the customers' needs [13]. This definition seems to fit well to the job of the traditional travel agent work that deals with understanding the customers' requirements and providing them with high-added value services [10]. This innovation in the industry has been advocated by Morgan \& Trivedi [14] who point out that the travel agents value relies on the customers' need of understanding, not in the booking process.

In operational terms, this means that customers transfer to the travel agent the care to find the package that best fits with his/her expectations. This is a high information and fares selection process necessary to design the best self-tailored package [4].

The relevancy of service quality and expertise sharing in the service provided by traditional travel agencies has been proved in an empirical study conducted in Hong Kong by Lam \& Zhang [15]. The two authors have conducted a survey research among 209 travel agents in Hong Kong in which they evidence a large breach between customer expectations and perceptions. Moreover, they outline that corporate image is not a factor that influences the perceived service quality. So, yet in 1998, the two authors suggested travel agencies to focus on the human capital and make investments on it. In practise, the implementation of a long-term plan of training and management of employees was supposed to be the right direction to improve the quality of the service provided and guarantee the survival of agencies.

The gap between travel agencies and customers' expectations has also been studied through game-theoretic tests. A sample of 198 hotel customers who booked a hotel room through a travel agent in the six months before their stay have been tested: results show that the higher the room rate, the less the value perceived by the consumer and vice-versa [14].

Expertise and know how (i.e., tacit knowledge) repre- sent the added value provided by travel agencies. This is confirmed by an international online survey conducted upon 132 individuals. The research has pointed out that travel agents are perceived as more effective than the Internet in terms of providing a more comprehensive idea of the destination as well as of the whole journey. Also, the quality and the choice of the information offered are better than those provided by Internet [16].

But the role of ICT is also important for travel agencies to survive and being competitive. This is the main finding of a survey research conducted among random sample of 84 Canadian and 83 New Zealander travel agents designed to assess the relevancy of ICT systems among the travel industry [12]. Again, as put above, the Internet and other ICT tools need to be seen as an opportunity, not necessarily a threat [17]. Lewis et al. [2] identify the upcoming challenges of the traditional travel agency industry need facing the following list: providing added-value services, making ICT use successful and developing customers' loyalty. The latter needs to be improved: only few traditional travel agencies have and use customers' databases to build effective marketing and sales strategies [10].

In Switzerland, travel agents are professionals in charge of informing, counselling, organising travels as well as providing accommodation, transportation and sometimes tour guide services to the travellers (source: Swiss Federal Office of Statistics http://www.bfs.admin.ch). In this country, the major airline "Swiss International Air Lines Ltd" cut commissions to its agents in 2005 (source: http://www.swiss.com).

According to IATA, the International Air Transportation Association (source: http://www.iata.org), the Swiss demand for flying is estimated at around CHF 3 billion per year. This means that, assuming an airline ticket duty of $7 \%$, which was the most common charge to flying carriers between 1998 and 2002 [6,7], the whole Swiss travel agency industry has lost approximately CHF 210 million per year.

In addition to these losses, 2005 data highlight that only one third of overall travel bookings were made through traditional travel agencies $[13,18]$. This trend has been confirmed in 2006, with "more than one fourth of Swiss making reservations for their holidays through the Internet that equals the traditional travel agencies" [19].

We learn from service science theory that it is not easy to price a service. This happens because of the characteristics of services that are, by definition, intangible, heterogeneous, instantaneous and perishable. Services are intangible goods: their production results in the creation of immaterial value. Such goods are invisible for the customers; the lack of standards to judge them objectively makes the production of services a pure individual experience. Also, the service experience is encountered by individuals: it is unique since non-replicable and then 
instantaneous. Indeed, most of the time, the production of a service results from an individual-to-individual transaction. Finally, services are perishable as it is impossible to stock, re-sale or give them back [20-22]). The pricing of a service relies upon three pillars: internal organisational costs, the competitors' prices and the perceived value by the customers [20].

However, customers do not always perceive such value: making individuals aware of the worth of intangibles is not easy, not all individuals acknowledge it and perceptions may differ a lot. In the case of the travel agencies, a survey research conducted in the Geneva area in 2006 has evidenced that clients are aware of the value of the service provided but they are not ready to pay for it [23]. Further analysis on Geneva customers has highlighted the importance of the travel agents' expertise: this knowledge is considered as very useful but, again, individuals are not willing to pay to benefit of it [13].

In this research, we attempt to explore the perceived value of a service experienced by a customer between the travel agency walls. Thus, we aim to discover individuals' Willingness-To-Pay (WTP, see for example $[24,25]$ ) for a travel agency service experience. Therefore, would like to know whether travel agencies provide sufficient perceived value to their customers to be profitable [24].

To attempt to provide an answer to this concern, we have designed a theatre-based experimental study to identify some key patterns associated to this issue: experimentation is widely used in many environmental, psychological and service science studies to attempt to detect WTP for services or non-marketed goods [26-28].

This paper is organised as follows: in the next section, we present the methodology employed in our experimental study. We also outline the importance of using human simulation in making visible the value of such service experience. Then, we present the main results of our experiment and hypotheses have been validated through non-parametric statistical tests.

\section{Methodology}

To attempt understand individuals' WTP for the travel agent's service, we have made a theatre-based experiment. Tests were held at two separate groups of subjects (mainly adult professionals working in the public or private sector) who attended the Geneva Haute École de Gestion annual Symposium, on November $28^{\text {th }} 2007$.

To make visible the travel agent service experience, we have designed a short theatre libretto played before our subjects. The choice of a theatre experience relies upon a well-established tradition of these techniques in business. Theatre for business and organisations has also been recognised to have didactic qualities: it is considered as extremely useful for teaching communication, improving the oral expression, ameliorate employees' sales techniques, languages teaching and learning. Also, it is acknowledged to have pedagogic merits such as making individuals feel part of a group, being a manager and making communication easier, [29].

Furthermore, a survey on business students and executives who have followed a theatre-based training agree by underlying the importance of the theatres' development [30]. Finally, theatre-based techniques allow overseeing individuals in their completeness: this means that individuals' intellectual, physical and emotional dimensions are explored [31].

Thanks to this acknowledged usefulness of theatre in solving management and organisational issues, we have designed a theatre-based experiment representative of the service production and consumption in a Swiss travel agency. We have used theatre-based techniques in order to price the perceived added value of a typical travel agent service in Switzerland.

We call by "theatre-based experiments" tests held in a theatre-like space, in which there are two parties: actors and spectators. We plotted two hypothetical Swiss travel agency services and customer experiences and made them visible to two independent groups of individuals. Two professional actors (a man and a woman) on stage had to play two scripts showing two travel agents' consulting service experiences and spectators were asked to price them through the customer's side. More in detail, actors played two scripts: a very low quality travel agent's service experience followed by a high standard one.

In the very low quality service experience, the customer, Mrs Pittet, an upper-class Geneva woman goes to a travel agency to organise a tour in Andalusia for a group of friends and herself. She regularly goes to that agency and she is always satisfied by the services provided by Mr Paul, one of the employees working there. However, that day Mr Paul is absent and another agent (man) is at her service. Mrs Pittet asks him for a personally designed tour in that region of Spain. She expects an outstanding travel, regardless of the total price of the journey. The agent doesn't show a customer-oriented behaviour: he suddenly answers a personal phone-call and then attempts to propose Mrs Pittet a catalogue-based tour. He is not an expert of Spain, he neither speaks Spanish but according to him, going to Spain is "an ordinary trip, everybody knows where to go and what to see". So, he insists on the quality/price of the packages on the catalogue that he continues to show her. Again, Mrs Pittet makes clear that the budget is not a priority and she wishes a personally designed and unforgettable adventure: the travel agent still continues to show his confidence towards the tour operator he has got several catalogues on hand and on his table. After a few minutes, the customer, nervous and unsatisfied by the agent's attitude, leaves the agency.

The second play shows a very high-quality travel agent service. The customer is a direction secretary 
(woman) who is tired, sad and anxious as the directors of the company she works for have decided to fly from Geneva to New York a few days later. This travel must be planned in a hurry and the directors always have high expectations. They will go to the American city for business and for shopping for a few days. The travel agent (man) starts by welcoming his customer and then listens to her requests. He attempts to reassure the customer, offers her a glass of water and when his mobile phone is ringing, he turns it off. He is a very professional man; he attempts to make his customer at ease and answers to all of her requests. Finally, he promises the customer to send her a bid the day after, gives her a business card and, again reassures her that everything will be fine. The customer leaves the agency reassured, relieved and thankful to the travel agent.

The two scripts were played in front of a group of spectators: we repeated the test twice, with two independent groups of adults who could not communicate with each other. So, on the public side, a group of spectators (35) assisted to both plays (5-8 minutes each). They were then asked to freely state their Willingness-To-Pay (WTP) [23-25,32]: each had to price the service experience as if she/he were experiencing it from the customer's side. WTP had to be elicited for both scenarios. The spectators were provided with a sheet of paper for both experience and were asked to write down their WTP in Swiss Francs.

The same experiment was replied with a second group of subjects (42) that could not interact with the first one. Each individual of the second group assisted to both plays and then was asked to elicit her/his WTP. For this second experiment, the spectators were asked to state their WTP by choosing among the following possible answers: CHF 0, CHF 50, CHF 100, CHF 150 and CHF 200. Each individual of this second group was asked to elicit her/his WTP for both scenarios.

\section{Operational Definition}

This experiment has been conducted in the occasion of the Geneva Haute École de Gestion Symposium entitled "Draw-me a service! Private and public administrations: new techniques to conceive and appraise your services" which took place on November $28^{\text {th }} 2007$ in the buildings of the school. During all day, participants were introduced to the underlying service science issues together with a selection of best practises relating to both the private and the public sectors. Each participant, mainly adults active in the locally-based private and public organisations paid CHF 170 for the whole day: among others, this gave us the opportunity to funding our tests made with the help of professional actors.

Thus, the experiment was held during the afternoon when participants had already been introduced to the main basic concepts of service management, that is to say, the IHIP paradigm (Intangibility, Heterogeneity, Instantaneity and Perishability, see [20-22]) and its practical applications.

Several participants (77 subjects in total) chose the two parallel sessions called "Service Design Workshop" without being informed in advance about the experiment running.

Two scripts were written by Mr Gaëtan Derache, a Lecturer in Communications at HEG, and attempted to show in a humoristic way two opposite service experiences: a low quality or unpleasant experience and a high standing one in which it was possible to outline the expertise and quality of the service provided. This clear-cut difference among the two service experiences was designed with the aim to make obvious the huge gap occurring between them.

The choice of using professional actors was driven by two main factors: first of all, their expertise in playing different roles in front of a wide public was judged as a condition sine qua non to make the representations credible towards a group of adult spectators paying to assist and participate to the experiment. Secondly, professional actors are able to replicate the plays several times in an identical manner. These conditions allowed us to replicate the experiment twice in front of two separate groups of adults.

We can mention a few issues related to the experiment: first, because the two groups are independent our experiment falls in the category of independent measure design which is also known as between subjects design. Second, in terms of factors, the dependent variable corresponds to the WTP stated by the respondents and the independent variable is represented by the individuals' perception produced by the two scenes played by the professional actors.

The physical environment in which the professional actors played the scripts, i.e., the School annual event, the classroom, the day of the week, the stage of the plays... that might have influenced the individuals' perceptions have not been changed along the experiments. Thus, the environmental variables could be as much as possible kept under control since, in the same day, time and place individuals have participated to an identical test.

The experimenter asked the participants to the experiment to sit in the classroom and to watch the coming short play to be presented in front of them. After the end of the demonstration, the experimenter asked the participants to state their WTP for this service experience by writing it on a provided document. Participants were not allowed to communicate with each other during and after the experience. (see Figure 1)

This document was then collected to all participants; afterwards, the second play followed. Again, after the end of the play, the experimenter asked the tested adults 
to state their WTP for the service experience they have just observed by writing it on a provided document. (see Figure 2)

After collecting this second document, an explanation of the experiment followed together with participants' questions and suggestions.

Immediately after that the first group of tested individuals left the classroom, a second group entered into the classroom without any contact with the previous one. The same experience was replicated with the same technique as described above. The only change that was made concerns the documents on which the participant had to state their WTP. For this second round, the following document model (Figure 3) was provided.

This means that individuals were not free to elicit their WTP at their convenience but had to choose among the four possible provided answers, i.e., CHF 0, CHF 50, CHF 100 and CHF 200. The choice of this scale is motivated by what we have learnt by a first attempt on how to price the service of the travel agent. CHF 0, CHF 50, CHF 100 and CHF 200 correspond to the fixed fee scheme that we have observed in Geneva main streets agencies. We have chosen a maximum choice of CHF 200 as this represents the acknowledged fee enabling the travel agency to be profitable when packaging a full journey. Thus, we assume that people selecting CHF 200 might have a higher or equal WTP to this amount. The

\section{PLAY 1}

How much would you be willing to pay for this service?

CHF

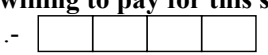

Figure 1. Play $1,1^{\text {st }}$ round

\section{PLAY 2}

How much would you be willing to pay for this service?

CHF

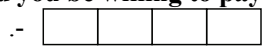

Figure 2. Play $2,1^{\text {st }}$ round

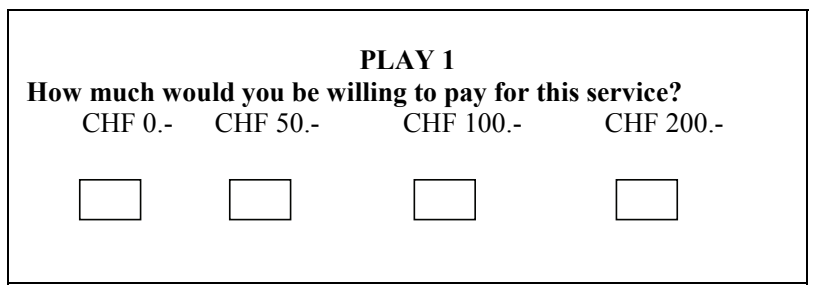

Figure 3. Play $1,2^{\text {nd }}$ round consistency of this scale is then verified when comparing the experiments associated with the overall free scale.

The above document was submitted to assess the WTP for the first play, i.e., the unpleasant service experience. Again, the participants to the test could not interact with each other. Then, the filled forms were collected, and the second script was played. Spectators were asked to state their WTP for this second play on the following document (Figure 4).

At the end of the plays, this second document collected, an explanation of the experiment followed together with participants' questions and suggestions.

\section{Results \& Hypothesis Testing}

We collected all papers and coded data with SPSS 15 for Windows software. Here follow the main findings issued by the analysis of the data collected.

For the first service experience, i.e., the low quality and unpleasant service experience, the stated WTP for both rounds is CHF 0 as collected in our sample. This means that in both cases, the elicitation tool (free WTP elicitation document and the multiple choice one) has no influence on the results. All adults who participated to the test agree not to be willing to pay anything for the service experience they had just observed.

The second service experience, that is to say the high quality service experience leads us with different WTP. First of all, participants who assisted to the first round and were free to elicit their WTP show a mean WTP of CHF 220.29 with a standard deviation of CHF 276.20. The median WTP is CHF 100 and the mode is CHF 100, on a range spanning from CHF 0 to CHF 1000 .

For the second round, where individuals were asked to state their WTP according to a provided scale (CHF 0, CHF 50, CHF 100 and CHF 200), the mean of the elicited WTP is CHF 117.85. The median WTP is CHF 100, the mode CHF 100 and the standard deviation CHF 66.09. In this second sample, the stated WTP spans from a minimum of CHF 0 and a maximum of CHF 200.

Thus, we can affirm that most spectators are willing to pay for the second service experience. Although the stated WTP does not assure that individuals would accept to pay the elicited amount $[26,28]$, we can affirm that individuals perceive a value in the second service experience

\section{PLAY 2}

How much would you be willing to pay for this service?

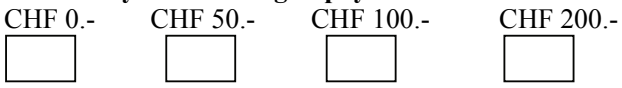

Figure 4. Play $2,2^{\text {nd }}$ round 
and are likely to pay for it. This result is confirmed by other researches in the tourism sector in which it is evidenced a positive relationship between customer satisfaction and stated WTP [25]. Frequencies for both rounds on the second service experience can be visualised as follows in Figure 5.

If we compare visually the two rounds WTP distribution as presented in Figure 5, we can see that Round 1 distribution displays more granularity than Round 2 distributions. This seems to be logical since participants could write down their WTP as they wanted. Nevertheless, both medians are identical. Moreover, looking at both samples, we notice that roughly one third of responses indicate a WTP of greater or equal than CHF 200.

Furthermore, we have tried to replace CHF 200 in round 2 answers' by CHF 509. This value has been calculated as the mean of equal or higher WTP than CHF 200 in round 1 . In this way, for both samples, we obtain a mean WTP of CHF 220.

As previously mentioned, the break-even point for a travel agent's service can be estimated at roughly CHF 200. This means that below this level, operational costs would be higher than revenues and several agencies won't be able to survive. Thus, we hypothesise that the value of a service experience perceived by clients must be far higher than its production cost to ensure the economical sustainability of the service. This is a condition sine qua non when making WTP and Price What You Want (PWYW) experiments: stated or observed cost need to be equal or higher than providers' operational costs [24].

Consequently, regarding the travel agency context, we would like to test if a typical travel agency service experience can provide sufficient intensity in terms of value perception to make people willing to pay enough to make this business profitable in the long run.

Official data for 2005 and 2006 announced that only one third of travels are booked through travel agencies $[18,19]$. This means that two thirds of the travels are re-

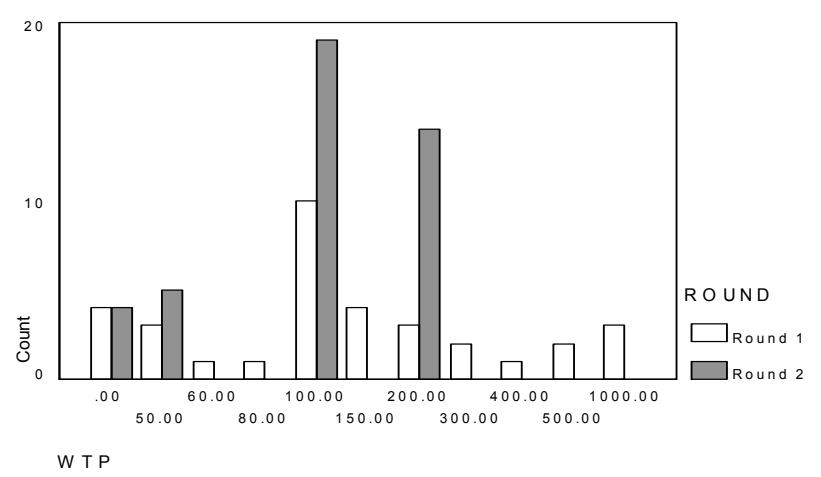

Figure 5. WTP distribution (1) served through other means. In our experiment, participants had the opportunity to see an outstanding service experience and were asked to price it. Thus, we would like to see in our experiment whether the proportion of individuals willing to pay CHF 200 or more the service experience differs from the current knowledge of one third buying through traditional travel agencies. For this reason we have designed the following hypothesis scheme:

Ho: There is a proportion of $2 / 3$ of individuals whose WTP is inferior to the required travel agency service fee.

Ha: There is not a proportion of $2 / 3$ of individuals whose WTP is inferior to the required travel agency service fee.

To test this hypothesis we have used a test called "binomial test for a dichotomous variable" [33] with a test proportion value of 0.666 that is to say $2 / 3$ of the sample. To make the test, we have recoded all values in order to have a dichotomous variable that relies upon two WTP classes: stated WTP under CHF 199 (Group 1) and stated WTP equal or superior to CHF 200 (Group 2). Thus, if the test shows that $2 / 3$ of the sample is willing to pay a sum inferior to CHF 200 for the travel agent service, and then the other $1 / 3$ is. Otherwise, we shall reject the null hypothesis and retain the one affirming that there is a different proportion between those willing to pay more than CHF 200 and those who are not.

We have tested the whole sample answers (round 1 and round 2) to verify our hypothesis. (see Table 1)

The p-value of the test being 0.363 , we fail to reject the null hypothesis. On the basis of the test we have made, we can affirm that $2 / 3$ of individuals have a WTP which is inferior to the required travel agency service fee. We can then conclude that only $1 / 3$ of the sample is willing to pay for at least the mainly adopted fixed fee by the Swiss travel agents.

We have also checked whether there are differences frequencies between the sample two rounds. Again, we have used the dichotomous variable as in the previous test. Participants assisted to the same service experience, but they were not allowed to interact with each other and they had different elicitation tools (free statement, provided multiple choice scale). We can visualise the distribution of the answers provided by the two rounds through cross-tables and diagrams (Table 2).

Table 1. Binomial test

\begin{tabular}{cccccc}
\hline & Category & $\mathrm{N}$ & $\begin{array}{c}\text { Observed } \\
\text { proportion }\end{array}$ & $\begin{array}{c}\text { Test } \\
\text { Prop. }\end{array}$ & $\begin{array}{c}\text { Asymp. } \\
\text { Sig.(1-tailed) }\end{array}$ \\
\hline WTP Group 2 & WTP $<200$ & 49 & 0.636 & 0.666 & $0.323(\mathrm{a})$ \\
Group 1 & WTP $>=200$ & 28 & 0.364 & & \\
Total & & 77 & 1.000 & & \\
\hline
\end{tabular}

a. Based on Z Approximation. 
Finally, we have made an additional to verify whether significant statistical differences exist between the two rounds we have made a test called "Chi-square for two unrelated samples". This test has been designed with the aim to check whether the elicitation tool used to measure subjects' WTP for the second plot makes statements significantly differ between round 1 and round 2 . For this reason we have designed the following hypothesis scheme:

Ho: There are no significant differences between WTP stated between the two rounds

Ha: There are significant differences between WTP stated between the two rounds

Table 2. Cross table: round $1 *$ round 2

\begin{tabular}{ccccc}
\hline & \multicolumn{2}{c}{ Rounds } & \multirow{2}{*}{ Total } \\
\cline { 3 - 4 } & Round 1 & Round 2 & \\
\hline \multirow{2}{*}{ WTP } & WTP $<200$ & 21 & 28 & 49 \\
\cline { 2 - 4 } & WTP $>=200$ & 13 & 15 & 28 \\
\hline Total & 34 & 43 & 77 \\
\hline
\end{tabular}

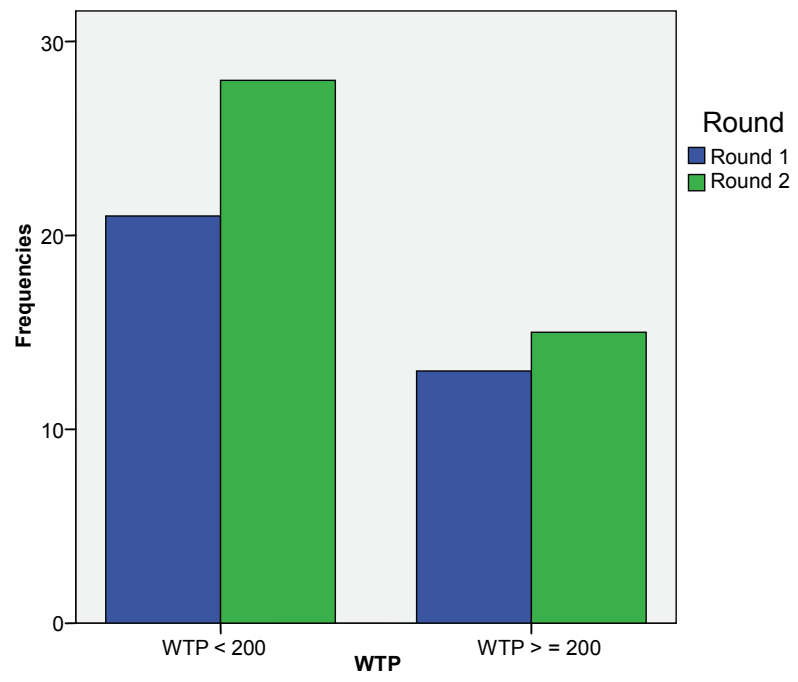

Figure 6. WTP distribution (2)

Table 3. Chi-Square tests

\begin{tabular}{lccccc}
\hline & Value & df & $\begin{array}{c}\text { Asymp.Sig. Exact Sig. Exact Sig. } \\
\text { (2-sided) }\end{array}$ & (2-sided) & (1-sided) \\
\hline $\begin{array}{l}\text { Pearson Chi-square } \\
\begin{array}{l}\text { Continuity Correc- } \\
\text { tion(a) }\end{array}\end{array}$ & 0.092 (b) & 1 & 0.761 & & \\
$\begin{array}{l}\text { Likelihood ratio } \\
\text { Fisher's Exact Test }\end{array}$ & 0.092 & 1 & 0.948 & & 0.762 \\
$\begin{array}{l}\text { Linear-by-Linear } \\
\text { Association }\end{array}$ & 0.091 & 1 & 0.763 & & \\
N of valid cases & 77 & & & & \\
\hline
\end{tabular}

a. Computed only for a $2 \times 2$ table

b. 0 cells $(0.0 \%)$ have expected count less than 5 . The minimum expected count is 12.36 .
The p-value of 0.761 for this test show lets us to fail-to-reject the hypothesis of differences between the rounds. We can then affirm that there are no statistical difference in the dichotomous variable provided by the spectators of the first and the second round.

\section{Conclusions}

Traditional (physical) travel agencies are suffering the current changes in the tourism industry. This is caused mainly by the cut of airline commissions and the use of Internet that offers customers direct booking to travel service providers as well as web travel agencies. Both factors have severely affected the travel agency industry that should redesign itself. Thus, travel agents shall become travel "consultants" or travel "experts" instead of booking employees.

Therefore, we assist to a change in the job of the travel agent, which becomes more and more a high added-value service. Customer service associated with technical knowledge and the agent's expertise become crucial in the production of the travel agency service experience. The value of the service provided must be well acknowledged by customers who should accept to pay the agencies an adequate sum to make this kind of business profitable. So, the overall customers' willingness to pay (WTP) for travel agency services experience should be sufficient to cover the agencies' operational costs and to make profits.

To deal with this service pricing issue, we have designed a theatre-based experiment that has been run on 77 subjects participating to a Geneva Haute École de Gestion annual event presenting service management issues for both private and public organisations. Two professional actors have played two scripts in which they showed the spectators two opposite travel agents service experiences: a low quality and an outstanding one. At the end of each play, participants were asked to state their WTP for this service experience. The same service experiences were showed to two different groups of adults that could not interact with each other but had different WTP elicitation tools. Participants of the first group were free to state their WTP for both service experiences on a provided document while those of the second group should choose their WTP on the basis of a provided scale (CHF 0, CHF 50, CHF 100 and CHF 200).

Since the travel agencies operational costs for a travel package can be estimated at about CHF 200, we have gathered together the two rounds data and divided them into two sets: values below CHF 200 and those equal or above this sum. This has allowed us to have a data set in which it was possible to identify the individuals willing to pay a sufficient travel agency fee to make their business sustainable and those who are not, and would rather use alternative tools to organise their travels.

Official data show that in Switzerland, in 2005 and 
2006 only one third of travels were booked through travel agencies. We have conducted a non-parametric statistical test to verify whether the same proportions apply to our small sample that assisted to a human simulation of an outstanding travel agent service experience. Our test evidenced that the same proportion apply to our participants: $2 / 3$ are not willing to pay a sufficient sum for the travel agent service to cover its operational costs and being profitable. Also, a further test has evidenced that no significant statistical difference exists between the stated WTP of participants to the first round and to the second one.

Finally, we can conclude that only one third of customers are willing to pay a sufficient fee for a travel agency service experience. The perceived value of the service provided expressed in monetary terms is in a general manner not sufficient to cover the agencies operational costs. In fact, people are not ready to properly assess the value provided by the travel agent. We have observed this attitude in real context since in the past years agencies services were provided for free. Consequently, their worth might not have been fully acknowledged.

\section{Acknowledgements}

An earlier version of this paper was presented at the $4^{\text {th }}$ International Conference on Services Management "Managing Services across Continents", Oxford Brookes University, UK, May 8-9, 2009. Thus, we would like to thank these participants as well as an anonymous referee for their valuable feedback.

\section{REFERENCES}

[1] P. C. Alexander, "Travel Agency Bankruptcies: A Primer," Commercial Law Journal, Vol. 106, No. 4, 2002, pp. 443-453.

[2] I. Lewis, J. Semeijn and A. Talalayevsky, "The Impact of Information Technology on Travel Agents," Transportation Journal, Vol. 37, No. 4, 1998, pp. 20-25.

[3] R. Dumazel and I. Humphreys, "Travel Agent Monitoring and Management," Journal of Air Transport Management, Vol. 5, No. 2, 1999, pp. 63-72.

[4] I. Lewis and A. Talalayevsky, "Travel Agents: Threatened Intermediaries?" Transportation Journal, Vol. 36, No. 3, 1996, pp. 26-30.

[5] Knowledge@Warton, "Will Commission Cuts Kill the Small Travel Agent?" May 8, 2002.

[6] Amadeus, "Service Fees and Commission Cuts-Opportunities and Best Practises for Travel Agencies," 2007.

[7] F. Alamdari, "Regional Development in Airlines and Travel Agents Relationship," Journal of Air Transportation Management, Vol. 8, No. 5, 2002, pp. 339-348.

[8] S. Dolnicar and C. Laesser, "Travel Agency Marketing Strategy: Insights from Switzerland," Journal of Travel Research, Vol. 46, No. 2, 2007, pp. 133-146.
[9] J. Levere, "Changing Roles," Airline Business, October 2000.

[10] J. Dilts and G. Prough, "Travel Agencies: A Service Industry in Transition in the Networked Economy," Marketing Management Journal, Vol. 13, No. 2, 2002, pp. 96-106.

[11] M. M. Bennett and C.-W. K. Lai, "The Impact of the Internet on Travel Agencies in Taiwan," Tourism and Hospitality Research, Vol. 6, No. 1, 2005, pp. 8-23.

[12] S. Deng, R. Lawson and L. Moutinho, "Travel Agents' Attitudes towards Automation and the Delivery of a Service," Asia Pacific Journal of Marketing and Logistics, Vol. 4, No. 12, 2000, pp. 60-72.

[13] J. Debély, M. Dubosson and E. Fragnière, "The Travel Agent: Delivering More Value by Becoming an Operational Risk Management," Proceedings of the $9^{\text {th }}$ International Research Seminar in Service Management, La Londe, IAE Aix-en-Provence, France, May 30-31 \& June 1-2, 2006, pp. 178-203.

[14] M. S. Morgan and M. Trivedi, "Service Intermediaries: A Theoretical Modeling Framework with an Application to Travel Agents," Journal of Modelling in Management, Vol. 2, No. 2, 2007, pp. 143-156.

[15] T. Lam and H. Q. Zhang, "Service Quality of the Travel Agents: The Case of Travel Agents in Hong Kong,' Tourism Management, Vol. 20, No. 3, 1998, pp. 341-349.

[16] A. Bodganovych, H. Berger, S. Simoff and C. Sierra, "Travel Agents vs. Online Booking: Tackling the Shortcomings of Nowadays Online Tourism Portals," Proceedings of the ENTER'06 Conference, Lausanne, Switzerland, 2006, pp. 418-428.

[17] L. Suárez Álvarez, A. M. Diáz Martín and R. Vázquez Caselles, "Relationship Marketing and Information and Communication Technologies: Analysis of Retail Travel Agencies," Journal of Travel Research, Vol. 45, No. 4, 2007, pp. 453-463.

[18] Credit Suisse, "Swiss Issues-Le Marché des Voyages: Entre Globalisation et Pression des Coûts," 2005.

[19] Credit Suisse, "Dynamisme de la Branche des Agences de Voyage Malgré la Concurrence d'Internet-Marché Suisse des Voyages: Offre, Demande et Perspectives," 2007.

[20] G. Catenazzo and E. Fragnière, "La Gestion des Services [Services Management]," Economica, Paris, France, 2008.

[21] C. Hsu, "Service Science: Design for Scaling and Transformation," World Scientific, Singapore, 2009.

[22] T. Laine, J. Paranko and P. Suomala, "The Nature of Services in the Business-To-Business Context," In: Mendibil, K. and Shamsuddin, A. Eds., Moving up the Value Chain, University of Strathclyde, Glasgow, Scotland, 2006, pp. 887-896

[23] J. Debély, M. Dubosson and E. Fragnière, "The Pricing of Knowledge-Based Services: Insights from the Environmental Sciences," Journal of Services Research, Special Issue (February 2008), 2008, pp. 167-181.

[24] J.-Y. Kim, M. Natter and M. Spann, "Pay What You Want: A New Participative Pricing Mechanism," Journal of 
Marketing, Vol. 73, No. 1, 2009, pp. 44-58.

[25] C. Homburg, N. Koschate and W. D. Hoyer, "Do Satisfied Customers Really Pay More? A Study of the Relationship between Customer Satisfaction and Willingness to Pay," Journal of Marketing, Vol. 69, No. 2, 2005, pp. 84-96.

[26] G. Garrods and K. G. Willis, "Economic Valuation of the Environment, Methods and Case Studies," Edward Elgar, Cheltenham, UK, 1999.

[27] A. Hansla, A. Gamble, A. Juliusson and T. Gärling, "Psychological Determinants of Attitude towards and Willingness to Pay for Green Electricity," Energy Policy, Vol. 36, No. 2, 2008, pp. 768-774.

[28] R. Hoevenagel, "An Assessment of the Contingent Valuation Method," In: Pethig, R. Ed., Valuing the Environment: Methodological and Measurement Issues, Kluwer Academic Publishers, Dordrecht, The Netherlands, 1994, pp. 195-227.

[29] M. Salgado, "Utiliser le Théâtre "Dans" et "Pour" L’En- treprise," Proceedings of the XIVth International Conference of the International Association of Strategic Management (AIMS), Angers, France, June 6-9, 2005, pp. $1-28$.

[30] M. Salgado, "Formation au Management: Les Vertus du Théâtre en Formation Continue et en Formation Initiale," $14^{\text {th }}$ Colloque National de la Recherche en IUT, LyonVilleurbanne, France, May 29-30, 2008a, pp. 1-8.

[31] M. Salgado, "Le Théâtre, un Outil de Formation au Management," Revue Française de Gestion, Vol. 34, No. 181, 2008b, pp. 77-96.

[32] N. Nomura and M. Akai, "Willingness to Pay for Green Electricity in Japan as Estimated through Contingent Valuation Method," Applied Energy, Vol. 78, No. 4, 2004, pp. 453-463.

[33] A. Bryman and D. Cramer, "Quantitative Data Analysis for the Social Scientist with SPSS 15 \& 16," Routledge, London, 2006. 